\title{
Privação e estado de nulidade: significações da ontologia do mal no pensamento de Agostinho de Hipona ${ }^{1}$
}

\author{
Darlan Lorenzetti ${ }^{2}$
}

Resumo: O presente trabalho visa analisar aspectos referentes à problemática do mal, e, por conseguinte, elementos de sua nulidade ontológica no pensamento de Agostinho de Hipona. Para tanto, toma como referência sobretudo alguns pontos de reflexão empreendidos pelo Bispo de Hipona em sua obra clássica sobre o tema: o diálogo O livre-arbítrio. Inicialmente procura demonstrar a similaridade existente entre a compreensão firmada por Agostinho e o entendimento anteriormente apresentado pelo pensamento grego, sobretudo de viés platônico em torno à questão do mal. Assim como compreendia Platão, Agostinho afirma a noção de mal de um ponto de vista negativo, isto é, o mal só adquire estatuto ontológico na medida em que se constitui como contradição, carência e afastamento do Bem, ou seja, da plenitude do Ser em sentido metafísico. Assim sendo, a reflexão busca demonstrar como na perspectiva agostiniana este Ser, em estado de plenitude e perfeição ontológica, é pensado e definido como Deus. Sendo Deus criador de todas as coisas existentes, não poderia ser ele o ente gerador do mal. Deste modo, o mal assume caráter e sentido negativo do ponto da ontologia, sendo explicado como decorrência dos atos morais humanos empreendidos pelo livre-arbítrio.

Palavras-chave: Agostinho. Deus. Mal. Ontologia. Ser.

Privation and state of nullity: meanings of the ontology of the evil in Augustine of Hippo's thought

\begin{abstract}
This work pretends to analyze the aspects referring to the problem of the "evil" and, therefore, the elements of its ontological nullity in the thought of Augustine of Hippo. For this, we take as reference especially some points of the reflection of the Bishop of Hippo in his classical work about the topic, namely, the dialog De Libero Arbitrio. Initially, we try to demonstrate the similarity between the understanding by Augustine and the understanding previously presented by the Greek thought, especially of platonic bias, in the around of the question of the evil. As Plato, Augustine affirms the notion of evil from a negative point of view, that is, the evil that just acquire ontological status according as it constitutes itself as contradiction, lack and deviation of the Good, that is, of the fullness of the Being in the metaphysical sense. Therefore, the reflection aims to demonstrate how in the Augustine's perspective this Being in state of fullness and ontological perfection is thought and defined as God. Being God the creator of all existing things, couldn't be He the entity evil's generator. Therefore, the evil takes on character and negative sense from the point of view of the ontology, being explained as consequence of the human moral acts undertaken by the free will.
\end{abstract}

Keywords: Augustine. God. Evil. Ontology. Being.

\footnotetext{
${ }^{1}$ Trabalho originalmente elaborado como requisito de avaliação e parte de Trabalho Monográfico de Conclusão (TMC) sob orientação do Prof. Dr. Paulo César César Carbonari no Instituto Superior de Filosofia Berthier (IFIBE).

${ }^{2}$ Mestrando do Programa de Pós-Graduação em Filosofia da Pontifícia Universidade Católica do Rio Grande do Sul (PUCRS). E-mail: darlanlorenzetti@hotmail.com.
} 


\title{
Introdução
}

\author{
A problemática do mal, no conjunto das grandes questões que \\ moveram e constituíram o pensar filosófico ocidental como um \\ todo, ocupa desde sempre um locus central e determinante. Objeto \\ de profundas, obstinadas reflexões e especulações no decorrer de \\ toda a tradição filosófica ${ }^{3}$, a pergunta acerca da origem do mal chega \\ até nossos dias de forma retumbante e atual. Ler o problema desde \\ uma perspectiva histórico-filosófica, implica estar atento a \\ determinadas construções teóricas realizadas em torno do problema \\ que representam verdadeiros marcos conceituais e elucidativos.
}

\footnotetext{
${ }^{3}$ A significação deste termo num sentido filosófico tem uma extensão tão ampla quanto a do termo bem, uma vez que este é seu correlativo. Sua noção ao longo da tradição filosófica pode ser descrita segundo duas concepções fundamentais: o mal num sentido metafisico, no qual este é em primeiro lugar entendido como o não-ser e, em segundo lugar visto como uma dualidade do ser; a segunda noção possui um caráter muito mais subjetivista, e diz que o mal é fruto de um juízo negativo particular. A concepção metafisica do mal o considera o não-ser diante do ser que é, pois, o bem. Uma primeira referência de abordagem referente ao problema do mal, ainda que de maneira subliminar a encontramos na filosofia grega, mais precisamente no pensamento platônico. Platão constrói através de sua obra uma ontologia que é tida como puramente idealista. Desta maneira, um tema preponderante em seus escritos é o da ideia do Bem. Platão ocupa-se determinadamente a responder a seguinte interrogação: o que é o Bem? No livro VII da República, no qual encontra-se a alegoria da caverna, oferece-nos a seguinte descrição: "[...] na extremidade do mundo inteligível encontra-se a ideia do Bem, que apenas pode ser contemplado, mas que não se pode ver sem concluir que constitui a causa de tudo quanto há de reto e de belo no mundo: no mundo sensível, está ideia gera a luz e sua fonte soberana e, no mundo inteligível, ela, soberana, dispensa a inteligência e a verdade" (PLATÃO, 1989, p. 51). O mal apesar de se constituir como realidade, é carente de idealidade. A sua ocasião no mundo nada mais é do que consequência da imoralidade humana. A influência da compreensão platônica aparece primeiramente no pensamento dos estoicos e é posteriormente formulada com maior refinamento pelos neoplatônicos. Para os primeiros a existência do mal é condicionada pelo fato de necessariamente haver o bem, de modo que não haveria a justiça caso não houvesse ofensa, assim como não haveria a verdade não havendo a mentira. Do ponto de vista estoico, tudo o que existe é bom e o mal fica reduzido ao não-ser. Plotino no século III "[...] identifica o Mal com a matéria: a matéria é o não-ser. O Mal não consiste na deficiência parcial, mas na deficiência total” (ABBAGNANO, 2007, p. 638). Esta identificação entre mal e não-ser é retomada pela filosofia cristã, em nomes como Clemente de Alexandria, Orígenes, e mais expressivamente em Santo Agostinho, para quem "Nenhuma natureza é o Mal, e esse nome indica apenas a privação do bem" e "todas as coisas são boas, e o mal não é substância porque se fosse substância seria bem" (SANTO AGOSTINHO apud ABBAGNANO, 2007, p. 638). Esta doutrina encontra força ainda na obra de Boécio e em expoentes da Escolástica como Maimônides, Alexandre de Hales, Alberto Magno e por fim Tomás de Aquino. Segundo este "[...] o ser e a perfeição de qualquer natureza são essencialmente bem. Portanto, não pode acontecer que o mal signifique algum ser, alguma forma ou natureza; conclui-se, pois, significa apenas a ausência do bem” (TOMÁS DE AQUINO apud ABBAGNANO, 2007, p. 638).
} 
Com efeito, é inconcebível realizar tal tarefa de caráter investigativo sem remeter-nos de imediato à figura e ao legado de Santo Agostinho de Hipona4 (354-430 d. C).

Se as especulações humanas acerca do mal seguem afligindo os homens e mulheres no terceiro milênio, o mesmo se segue à grandiosidade da questão em âmbito filosófico. Pois bem, alguém poderia indagar qual a razão para dedicar-se a pensar o mal hoje e por que fazê-lo a partir da ótica de Agostinho de Hipona? Tal opção pode, primeiramente, ser justificada com base exatamente na atualidade inerente à questão. Muitos dos que caminham sobre a terra, ocupando-se ou não da filosofia, por esta ou aquela circunstância perguntam-se: afinal, de onde vem o mal? O que é o mal? Por que o mal? Portanto, observamos que se trata de uma questão que ainda persegue a filosofia como um todo, provocandolhe incômodo e inquietude.

Assim como ocorre de forma predominante e incisiva no pensamento grego clássico, o conceito de mal em Agostinho só existe como a negação e a contradição daquilo que é o Bem e o Ser em

\footnotetext{
${ }^{4}$ Boehner e Gilson em sua História da Filosofia Cristã, destacam que as informações relativas à vida e à carreira de Agostinho de modo geral são obtidas através de três fontes. Duas foram escritas pelo próprio Agostinho: As Confissões, que é sua autobiografia, e as Retratações. O outro escrito trata-se de uma biografia elaborada por seu amigo Possídio. "Nasceu Agostinho a 13 de novembro de 354 em Tagasta, hoje Souk-Aras, perto de Hipona, na província romana da Numídia. Seu pai era pagão, mas converteu-se antes de morrer. Sua mãe é Santa Mônica. Estudou, sucessivamente, em Tagasta, Madaura e Cartago. Lecionou retórica, primeiro em Cartago, depois em Roma, onde se desgostou com a conduta grosseira dos estudantes e, finalmente em Milão. Ali, o jovem começou a frequentar os sermões de Ambrósio, movido inicialmente, por um interesse puramente literário. A breve trecho, porém, sentiu-se tocado pelas palavras do bispo, e depois de muitas lutas interiores fez-se batizar (Sábado Santo de 387). Pouco mais tarde, deixou Milão para retornar à África. A meio caminho, na cidade de Óstia, faleceu-lhe a mãe. Agostinho demorou-se ainda cerca de um ano em Roma, e no outono de 388 está de volta em Tagasta, sua cidade natal. Pouco depois fundou uma espécie de mosteiro em sua casa paterna. Mas não tardou a ver-se arrancado ao seu retiro, a instâncias de Valério, bispo de Hipona, que o ordenou sacerdote e lhe confiou a missão de pregador. Alguns anos depois Valério fê-lo seu coadjutor e sucessor. Agostinho contava, então, 42 anos de idade. Faleceu a 28 de agosto de 430, durante o assédio da cidade episcopal pelos vândalos. Prendado de caráter extraordinariamente simpático, Agostinho exerceu uma atração irresistível sobre os contemporâneos. Sua mansidão e sua capacidade profundamente humana de compreensão, moderavam-lhe a passionalidade e exuberância púnicas. Conhecedor dos abismos do coração humano, contemplou-lhe também as mais sublimes alturas. Seu símbolo é um coração em chamas e o olhar voltado às alturas" (BOEHNER; GILSON 2003, p. 139-140).
} 
sentido metafísico. É assim que Agostinho edifica o seu conceito de Deus. Deus adquire um significado correspondente à perfeição e à plenitude do Ser. Deus é efetivamente o Ser. Deste modo, o mal só pode ser pensado em uma perspectiva de afastamento e carência de ser. Ontologicamente falando, o mal não é. Sua existência é então explicada por meio da existência do livre-arbítrio, que é invariavelmente o gerador do mal. A pergunta arrebatadora "unde male” (por que o mal?) ganha aqui eficaz resposta. O homem na condição de ser livre, pode dispor do livre-arbítrio decidindo assim afastar-se do Bem, isto é, de Deus.

\section{O mal enquanto estatuto ontológico}

A categoria filosófica “mal” em Agostinho, só é devidamente compreendida na medida em que apreendemos a significação de outros conceitos fundamentais, tais como vontade e liberdade. Contudo, "O problema depende essencialmente da metafísica, pois a vontade humana é apenas um fragmento da ordem universal. Para resolvê-lo é necessário partir da consideração do ser" (GILSON, 2006, p. 271).

No que tange aos temas imbricados à metafísica agostiniana como um todo, é imprescindível destacar a influência notável que Platão, ainda que indiretamente, exerce sobre Agostinho. No que se refere à questão do mal, é extremamente perceptível a correção existente entre o entendimento platônico e o agostiniano. ${ }^{5}$

\footnotetext{
${ }^{5}$ Ao analisarmos as influências filosóficas recebidas por Agostinho, Platão em geral é uma unanimidade. É possível perguntar, com efeito, como Platão chega a Agostinho? É um tanto quanto complexo definir qual o momento exato em que se dá este encontro. Contudo sabemos que a filosofia patrística tem contato com o platonismo desde o final do século II, o que faz supor que o estudo de Platão no contexto em que Agostinho vive, isto é, séculos IV e V, já era algo relativamente comum. Bertrand Russel, na História da Filosofia Ocidental, relata haver por parte de Agostinho "[...] uma descrição muito simpática de Platão, a quem coloca acima de todos os outros filósofos. Todos os outros têm de ceder-lhe lugar: 'Que Tales se vá com a sua água, Anaxímenes com o ar, os estóicos com o seu fogo, Epicuro com os seus átomos.' Todos eles eram materialistas. Platão não o era. Platão viu que Deus não é nenhuma coisa corpórea, mas que todas as coisas recebem a sua forma de Deus, e de algo imutável. Teve também razão ao dizer que a percepção não é a fonte da verdade. Os platônicos são os melhores na lógica e na ética, e os que mais se aproximam do Cristianismo. 'Diz-se que Plotino, que
} 
A análise platônica, muito provavelmente, é a primeira referência de abordagem referente ao problema do mal, ainda que de maneira subliminar. Platão constrói uma ontologia que é tida como puramente idealista. Desta maneira, um tema preponderante em seus escritos é o da ideia do Bem. Platão ocupa-se determinadamente a responder a seguinte interrogação: o que é o Bem? No livro VII da República, no qual encontra-se a alegoria da caverna, oferece-nos a seguinte descrição:

[...] na extremidade do mundo inteligível encontra-se a ideia do Bem, que apenas pode ser contemplado, mas que não se pode ver sem concluir que constitui a causa de tudo quanto há de reto e de belo no mundo: no mundo sensível, esta ideia gera a luz e sua fonte soberana e, no mundo inteligível, ela, soberana, dispensa a inteligência e a verdade (PLATÃO, 1989, p. 51).

Como se percebe, a ideia do Bem está associada à perfeição absoluta, ao puro ser. Contudo, seguindo a direção da filosofia antiga, ao falar do ser, Platão toma em consideração apenas o ideal, de modo que o mal se constitui como o não-ser. Platão é, em grande medida, o fundador de uma ontologia que influenciou todas as demais considerações posteriores que consideram o mal como uma privação do ser. Seu pensamento possui um caráter de afirmação do ser, de modo que "[...] no seu sistema filosófico o mal não entra em nenhuma categoria. O ser, que Platão reconhece como o ser verdadeiro e real, é somente o ser ideal" (HIRSCHBERGER, 1957, p. 81). O mal apesar de se constituir como realidade, é carente de idealidade. A sua ocasião no mundo nada mais é do que consequência da imoralidade humana.

O conceito de ser (esse) no agostinismo refere-se inteiramente a Deus. Agostinho irá enfrentar um problema de íngreme solução: 
como conciliar a existência/presença do mal no mundo com a existência de Deus? Temos, no fundo, uma questão epistemológica de justificação. Logo na introdução de $O$ livre-arbítrio ${ }^{6}$, o interlocutor de Agostinho, Evódio, expõe a angústia aparentemente inevitável: "Peço-te que me digas, será Deus o autor do mal?" (SANTO AGOSTINHO, 1995, p. 25). Agostinho prontamente vai ao cerne da questão:

Pois bem, se sabes ou acreditas que Deus é bom - e não nos é permitido pensar de outro modo -, Deus não pode praticar o mal. Por outro lado, se proclamarmos ser ele justo - e negá-lo seria blasfêmia -, Deus deve distribuir recompensas aos bons, assim como castigos aos maus. E por certo, tais castigos parecem males àqueles que os padecem. É porque, visto ninguém ser punido injustamente - como devemos acreditar, já que, de acordo com a nossa fé, é a divina Providência que dirige o universo - Deus de modo algum será o autor daquele primeiro gênero de males que nos referimos, só do segundo (SANTO AGOSTINHO, 1995, p. 25).

A problemática do mal, como já sabemos, é uma constante abordagem no pensamento agostiniano como um todo. Ao enfrentála, Agostinho busca dar resposta à maior questão de sentido existencial que pesava sobre o homem cristão no fim do século IV. Na tradição filosófica, muitos chamam a tentativa de justificação da existência de Deus frente à realidade do mundo de Teodiceia. E, de

\footnotetext{
${ }^{6}$ Diálogo de caráter teológico escrito por Santo Agostinho no decorrer dos anos 388 a 395, primeiramente em Roma e posteriormente em Hipona no norte da África, e que tem como personagens o próprio Santo Agostinho e seu amigo Evódio. A obra está estruturada e dividida em três livros. A temática inicial gira em torno do mal, isto é, sua natureza e a condição de sua existência. Um segundo ponto versa acerca do livre-arbítrio, uma capacidade que provém de Deus e que ao homem é atribuída, cabendo dele fazer bom uso. Trata-se de uma obra da juventude de Santo Agostinho e nela ele já apresenta, ainda que brevemente, alguns dos temas dos quais tratará nas suas obras posteriores, como a graça, a predestinação e o pecado original. Torna-se quase impossível falar em mal do ponto de vista ontológico-filosófico, sem remeter ao doutor de Hipona. Com este raciocínio Agostinho apresentou uma explicação para o problema do mal que, nas palavras de Reale, "se constituiu num ponto de referência durante séculos e ainda guarda a sua validade" (1990. p. 455) e que, por conseguinte, contribuiu para que ele se tornasse "o grande artífice da cultura ocidental da Idade Média” (1990. p. 434). Certamente estamos diante de um pensamento que guarda toda sua grandiosidade e profundidade e, portanto, merece ser revisitado e colocado na roda da discussão.
} 
fato, aqui a questão do mal adquire um sentido que se desenvolve justamente por este caminho. Ora, se Deus é bom, como pode haver o mal no mundo? Se formos a fundo, veremos que todo este caminho reflexivo pretende demonstrar que a presença/existência do mal em nada afeta ou põe em dúvida a existência e a bondade de Deus. Isso se deve, com efeito, ao estado de nulidade ontológica do mal. Conforme Coelho aponta:

Esta questão [...] foi de extrema importância para a formação pessoal de Agostinho, e ainda, evidentemente, para o itinerário filosófico adotado pelo bispo de Hipona. Além disso, sua resposta à questão da existência do mal no mundo foi de fundamental importância para o Cristianismo posterior, como atestam muitos comentadores e a própria Filosofia (COELHO, 2013, p. 13).

Ao analisarmos o conceito de Deus desde o ponto de vista ontológico, podemos destacar seu caráter de perfeição: “Deus é, por definição e em virtude das provas que estabelecem sua existência, o soberano bem. Sendo o bem supremo, não há nenhum bem acima ou fora dele" (GILSON, 2006, p. 271). A questão do mal insurge, deste modo, como uma aparente contradição geradora de profunda inquietação. ${ }^{7}$ De acordo com Nunes:

Para Agostinho, o problema do mal sempre se apresentou como um paradoxo, visto que a preocupação do hiponense era a de poder encontrar uma explicação para a origem do mal no universo criado e governado por um Deus sumamente bom e onipotente. Se Deus é perfeita bondade e onipotência, então o mal não pode existir.

\footnotetext{
${ }^{7}$ A questão do mal desde a Antiguidade e, portanto, da filosofia grega, era encarada como uma questão de caráter profundamente paradoxal. Agostinho será herdeiro desta tradição recebendo dela o desafio de apresentar uma solução aceitável ao problema. Ullmann, em seu breve ensaio intitulado $O$ mal ao referendar Epicuro, expõe com propriedade a complexidade para encontrar-se uma resposta satisfatória à questão, situação que se verifica desde os gregos. "Deus ou quer impedir os males e não pode ou pode e não quer; ou não quer e nem pode; ou quer e pode; se quer e não pode, é impotente o que é impossível em Deus. Se pode e não quer, é invejoso - o que, do mesmo modo, é contrário a Deus. Se nem quer nem pode, é invejoso e impotente; portanto, nem mesmo é Deus. Se quer e pode, que é o único conveniente a Deus, de onde provém, então a existência dos males? Por que não os impede?" (EPICURO apud ULLMANN, 2005, p. 28).
} 
Contudo, Agostinho percebia, desde a sua juventude, que o mal era uma realidade muito poderosa. Desse modo, como explicá-lo? Qual será a sua origem? Se admitimos a existência do mal, surge o desafio de buscar uma explicação para a sua origem. Quem será o autor do mal? Sendo assim, no que diz respeito à bondade do criador, ou temos de afirmar que Deus não é completamente bom, e dessa forma, permite o mal, ou afirmá-lo como autor do mal. Outra alternativa, ainda seria admitir que Deus não é onipotente e que, por isso, apesar de sumamente bom e querer evitar o mal, é impotente para impedi-lo. Assim, o dilema que se apresentava a Agostinho era o seguinte: como explicar a realidade do mal, sumamente bom e onipotente? (NUNES, 2009, p. 37).

No contexto histórico-filosófico de passagem do século IV ao século $\mathrm{V}$, a questão do mal estava consolidada como uma das mais importantes questões daquele locus temporal. Deste modo, a interrogação sobre a existência de tal princípio não era meramente um problema cristão. Pelo contrário, diversas correntes filosóficas que coexistem no período procuravam solucioná-la. Neste sentido, é inconcebível buscar analisar a formulação agostiniana sem dar atenção aos demais posicionamentos então erigidos. Muito provavelmente o maniqueísmo é o principal "adversário" do cristianismo neste contexto, na medida em que suas compreensões em torno do problema se contrapõem. Conforme escreve Montenegro, a temática do mal tem como pano de fundo o sentido histórico de sua presença no mundo:

Santo Agostinho desejou dar resposta a todas estas interrogações de seu tempo, de modo especial frente ao maniqueísmo, o qual bebe do dualismo zoroástrico-mazdeísta persa, que considera a existência de dois princípios divinos: Ahura-Mazda ou Ormuz, princípio do Bem, e Ahrímán, princípio do Mal. A partir daqui o dualismo masdeísta oferece uma visão da história humana, já que contrapõem os povos do bem, agricultores sedentários e vaqueiros civilizados, e os povos do mal, nômades ladrões e saqueadores. O dualismo evidentemente, supõe uma explicação simples para a grave questão da origem do mal. Entretanto, Santo Agostinho em seu processo de discernimento da Verdade, não se satisfez, 
compreendeu suas limitações e encontrou no platonismo uma resposta muito mais convincente (MONTENEGRO, 2012, p. 225).

Para além do maniqueísmo, podemos fazer menção a mais uma seita filosófica e religiosa relevante naquele contexto com a qual Agostinho também defronta-se: o donatismo, mesmo que, do ponto de vista da discussão acerca do mal, este não apareça com tamanha evidência em um sentido ontológico. ${ }^{8}$ A título de referência, pode-se elencar ainda o confronto de Agostinho com o pelagianismo. ${ }^{9}$ Com efeito, no que tange à discussão acerca do mal, o "grande adversário" do doutor de Hipona será o pensamento maniqueu. Para melhor compreendermos a oposição do filósofo àquela dualista do

\footnotetext{
${ }^{8}$ Svensson ao escrever sobre as Variações sobre o mal em Santo Agostinho, identifica a crítica ao donatismo num sentido paralelo à constituição das duas cidades, temática largamente abordada por Agostinho em A cidade de Deus. Ressalta Svensson: "Com efeito, a discussão com o donatismo é uma discussão sobre eclesiologia, e a princípio, a eclesiologia se apresenta como um dos campos teológicos mais distantes da filosofia. Poderíamos sintetizar o conflito entre Agostinho e os donatistas em torno da seguinte pergunta: Que valor tem os sacramentos administrados pelos bispos que nos momentos de perseguição não permaneceram firmes, sendo que entregaram códices das Escrituras aos perseguidores, convertendo-se assim em traidores? Esta questão foi fundamental para o desenvolvimento da doutrina dos sacramentos, porém também para a concepção agostiniana de mal. Não já para os aspectos ontológicos aos quais o levavam a controvérsia antimaniquéia, mas sim para outros aspectos do problema. A posição de Agostinho consiste em uma afirmação do valor da ação sacramental independente da qualidade moral do agente, porém tal posição doutrinal passa precisamente por um reconhecimento do caráter moralmente misto da Igreja. Para o donatismo, pelo contrário, o que é inconcebível é precisamente a ideia de que pode haver na Igreja uma convivência pacífica entre os maus e os bons. Com segurança o texto que Agostinho mais frequentemente cita a respeito disso, é o chamado de Cristo a não separa o trigo do joio antes do fim. Precisamente isto é algo que no solo teológico é uma observação que em certo sentido poderíamos considerar como algo que conduz a uma espécie de 'doutrina agostiniana da tolerância”' (SVENSSON, 2009, p. 72).

${ }^{9}$ Svensson analisa também o embate entre Agostinho e os pelagianos nos seguintes termos: "Se as discussões com um movimento popular norte-africano, como o donatismo, podem dar uma primeira impressão de serem poucos interessantes para a filosofia - impressão que não parece de todo correta - a posição de Agostinho contra um movimento de elite como o pelagianismo pode dar a impressão de ter transformado Agostinho em um autor antifilosófico. Com efeito, são abundantes nos escritos pelagianos as acusações de "vulgar" ou "púnico" a Agostinho. É acusado além disso de recair no maniqueísmo. Não faltam textos de Agostinho para fundamentar uma acusação como essa [...]. Quero limitar-me a apenas um exemplo de um texto agostiniano de caráter antipelagiano em que essa ênfase do poder do mal sobre nós não parece ir contra a tradição filosófica, mas pelo contrário, parece enriquecê-la [...]. A agudeza com que Agostinho descreve a ausência de domínio sobre a vontade mal, me parece ser, uma clara amostra do positivo desenvolvimento produzido por sua visão pessimista do homem [...]. A saída prática que aqui se oferecerá a uma parte do problema do mal, consiste na suposição de que somos privados da graça” (SVENSSON, 2009, p. 75-77).
} 
maniqueísmo, precisamos levar em conta alguns fatores fundamentais e determinantes. Para Coutinho, a isto

[...] se seguem duas inferências preliminares primordiais: $1^{\mathrm{a}}$ que, segundo o Maniqueísmo, ambos os princípios, Bem e Mal, existem ontologicamente; $2^{\mathrm{a}}$ que, sendo o homem a junção natural destes princípios, decorre que ele é naturalmente bom e mau. Dito de outra forma, esta concepção ontológica e cosmológica maniquéia não confere a Deus o estatuto de Ser Supremo. Criador de todas as coisas e acima do qual não existe nada maior, conforme professa o Cristianismo. Não obstante, a constituição do homem, tal compreende o Maniqueísmo, concebe-o destituído de liberdade, uma vez que todas as suas ações nada mais são do que o resultado de uma inclinação natural, ora para o bem ora para o mal. E, não havendo liberdade humana, tampouco há responsabilidade moral (COUTINHO, 2010, p. 125).

Sabemos que por determinado período Agostinho deixou-se influenciar pelas ideias maniqueístas, conduta que ele próprio julgou errônea nas Confissões ${ }^{10}$. A categoria de natureza é aqui fundamental, já que do ponto de vista ontológico toda natureza, enquanto obra criada, é boa. Agostinho nos mostra que:

Toda criatura justa ou pecadora contribui para a ordem universal. Deus, é, pois, o Criador de todas as naturezas: não somente daquelas que haveriam de pecar. Estas Deus as criou não para que não pecassem, mas para que acrescentassem algo à beleza do

\footnotetext{
${ }^{10} \mathrm{O}$ Livro V das Confissões nos relata com riqueza de detalhes a estada de Agostinho em Roma e Milão, período este em que aproximou-se dos ideais no maniqueísmo. No capítulo X deste livro ele "confessa" seus erros maniqueístas: "Ainda então me parecia que não éramos nós que pecávamos, mas não sei que outra natureza, estabelecida em nós. A minha soberba deleitava-se com não ter as responsabilidades pela culpa. Quando procedia mal, não confessava minha culpabilidade, para que me pudésseis curar a alma, já que Vos tinha ofendido, mas gostava de a desculpar e de acusar uma outra coisa que estava comigo e que não era eu [...]. Daqui deduzia eu a existência de uma certa substância do mal que tinha a sua massa feia e disforme - ou fosse grosseira como a que chamam terra ou tênue e sutil como o ar - a qual eu julgava ser o espírito maligno investindo a terra. E porque a minha piedade, como quer ela fosse, me obrigava a crer que a bondade de Deus não criou nenhuma natureza má, estabelecia eu duas substancias opostas a si mesmas, ambas infinitas: a do mal, mais diminuta e a do bem mais extensa. Deste princípio pestilencial provinham as restantes blasfêmias (SANTO AGOSTINHO, 1988, p. 108-110).
} 
universo, quer consentido, quer não ao pecado. [...]. Do mesmo modo, aquelas outras criaturas que podem pecar ou não, no caso de não existirem, a ordem do universo não se alteraria. Nesse caso, entretanto, muito de considerável teria faltado. Posto que, com efeito, são almas racionais, por certo dessemelhantes por suas funções daqueles espíritos superiores, mas igualando-os em sua natureza. E abaixo delas, há ainda muitos outros graus de ser que, sendo obras do Deus supremo, permanecem dignas de louvor (SANTO AGOSTINHO, 1995, p. 186-187).

Vemos, assim, que a refutação à existência de um princípio mau que possua em si um conteúdo ontológico, aponta para o conceito de corrupção que, na metafísica agostiniana, é extremamente caro.

\section{O ser pensado a partir de Deus}

Como já enfatizado, a imutabilidade é um elemento inerente e constitutivo do Ser, isto é, de Deus: “Assim, Deus não pode mudar uma vez que, não havendo qualquer bem a ser adquirido, ele não tem nada a perder nem a ganhar" (GILSON, 2006, p. 271). No que concerne à existência das criaturas divinas, imutabilidade e eternidade são categorias que não se aplicam à sua condição. Embora saibamos que é por meio de Deus que elas existem, elas não são parte do ser num sentido de identidade. Evidentemente se fossem elas idênticas a Deus, já não seriam criaturas. Conforme aponta Gilson:

A origem delas, sabemos, é totalmente outra. Criadas, elas foram tiradas do nada por ele. Ora, o que vem do nada não participa somente do ser, mas do não ser. Logo, nas criaturas, há um tipo de falta original que, por sua vez, engendra a necessidade de adquirir e, consequentemente, de mudar. Tal é a origem metafísica de sua mutabilidade. É o que quer exprimir a filosofia de Platão ao dizer que as coisas não podem ser ditas absolutamente ser nem não ser: nec omnio esse nes omnio nom esse. A dificuldade é precisa a 
relação do ser com o não-ser em cada caso particular (GILSON, 2006, p. 272).

Encontramos em todas as criaturas uma razão de seu ser. Elas só são na medida em que pertencem a Deus, ou seja, sua vida dele provém. Assim como nenhuma criatura é eterna e imutável como o é Deus, a existência só pode ser amada na medida em que vem daquele que é por excelência o Ser.

Pois, se fosses, feliz gostaria certamente antes existir do que não existir. E agora que existes, mesmo infeliz, preferes ainda existir, infeliz que sejas, a não existir em absoluto, embora recusando-se a ser infeliz. Considera pois, o quanto podes, quão excelente bem é a existência em si mesma, objeto do querer dos felizes e dos infelizes. Pois, se prestares bastante atenção, verás primeiramente que és infeliz na medida mesma em que não te aproxima do Ser supremo. Por outro lado, crês preferível o não-ser a uma existência miserável, na mesma medida em que perdes de vista esse sumo Ser. Entretanto, tu te apegas à existência, porque recebeste o ser d'Aquele que é o Ser supremo (SANTO AGOSTINHO, 1995, p. 171-172).

De acordo com Gilson, existem três atributos universais que fazem as coisas criadas, independentemente de sua substância (espiritual ou corporal) serem boas. A todas elas Deus dotou de medida, forma e ordem (modus, species, ordo): "Se essas três perfeições forem grandes a criatura que as possuir será um bem grande; se forem modestas, essa criatura será apenas um bem modesto; se forem nulas, a criatura não será nenhum bem” (GILSON, 2006, p. 272). Agostinho toma como princípio fundamental a noção de que todo ser é bom e que o mal consiste unicamente em uma privação. Vejamos seu conceito de natureza:

Denomino 'natureza' o que habitualmente se designa pela palavra 'substância'. Consequentemente, posso dizer que toda substância é Deus ou procede de Deus, e assim tudo o que é bom é Deus ou procede de Deus (SANTO AGOSTINHO, 1995, p. 192). 
A categoria "nada" aqui é situada desde a perspectiva da nulla natura, isto é, da natureza nula, inexistente. Dotada destas três perfeições, toda natureza, à medida que é criada, configura-se como boa: "Se assim é o bem, o mal só pode ser a corrupção de uma das perfeições na natureza que a possui” (GILSON, 2006, p. 273). Erculino, ao indagar sobre As origens do mal em Agostinho, pondera que

\begin{abstract}
De início, veremos que, para responder a questão "onde está o mal?” Agostinho desenvolve uma ontologia em que Deus é a única essência e todas as coisas são substâncias boas, logo o mal não possui existência por si como matéria. Como indicaremos, Deus é e faz as outras coisas serem; Ele é o único ser que existe por si, todas as outras coisas são por Ele sustentadas. As ideias a partir das quais Deus criou o mundo, são os seus pensamentos e a criação realizada ex nihilo é sustida pelo divino criador; por essa razão a matéria com a qual as coisas são feitas é boa. Ao mesmo tempo, em todas as coisas Deus colocou medida, ordem e número, tríade que faz com que a coisa tenha perfeição, beleza e bondade. Assim, tudo o que existe é feito, também, com formas boas, constituindo uma relação ontológica entre ser e bem (ERCULINO, 2014, p. 4).
\end{abstract}

Estamos diante da grande novidade legada por Agostinho ao universo da discussão ontológica. O mal aparece numa dimensão necessariamente relacionada ao bem, isto é, o mal só pode ser pensado a partir do bem. $\mathrm{O}$ mal constitui-se enquanto privatio. "Com efeito, ele é a privação de um bem que um sujeito deveria possuir, uma falta de ser o que ele deveria ser, e, por conseguinte um puro nada” (GILSON, 2006, p. 273). Assim sendo, é lógico inferir que

[...] o mal não existe dentre os objetos naturais, não é substância, nem tem existência ontológica. Isso revela a mudança significativa no pensamento da época realizado por Agostinho, já que em sua teoria o mal não é necessário para a perfeição do Todo. $\mathrm{O}$ mal não faz parte do ser, é a destruição do ser. [...] partindo do princípio da inexistência do mal na natureza, o Bispo de Hipona volta-se para 
investigações sobre o sujeito, donde conclui que o mal verdadeiro é o erro humano realizado pela vontade má (ERCULINO, 2014, p. 4).

É extremamente importante ressaltar o postulado agostiniano do mal num sentido e numa natureza exclusivamente niilista. Aqui encontra-se o núcleo duro da ontologia negativa de Agostinho. Temos uma radical e decidida afirmação do ser como princípio existente e do não-ser como fator ocasionado a partir da falta. Agostinho consegue com maestria salvaguardar a perfeição e o estatuto divino de Ser supremo. O bispo de Hipona vai ainda mais além ao demonstrar que a natureza, enquanto obra criada e expressão do ser de Deus, merece ser louvada. Assim, o mal não provém nem de Deus e nem mesmo de suas criaturas enquanto tais:

Uma vez que essas verdades tenham sido firmemente estabelecidas, como ponto de partida de nosso raciocínio, atende, (ó Evódio), ao que vou dizer: toda natureza racional, tendo sido criada com o livre-arbítrio da vontade, é, sem dúvida alguma, digna de louvor, caso se mantenha fixa no gozo do Bem supremo e imutável. A mesma coisa quanto à natureza racional que se esforça por se fixar nele permanentemente deve ela igualmente ser louvada. Pelo contrário, toda natureza que não esteja fixa naquele Bem supremo e recusar-se a trabalhar para aí se manter, é digna de ser censurada (vituperanda est), na medida em que aí não estiver e não fizer o necessário para isso (SANTO AGOSTINHO, 1995, p. 192).

Vejamos o que diz Coutinho acerca disso:

Em suma, o mal é a privação ou defecção do bem, das perfeições constitutivas de toda e qualquer natureza, é a ausência de ser [...]. Em oposição à dualidade maniquéia. Agostinho instaura o Bem como único princípio existente - Deus - e o mal como sua simples negação. Em outras palavras, o mal, na concepção agostiniana, não tem existência ontológica, não é, portanto, um princípio de força antagonicamente equiparada ao bem, como supunham os maniqueus [...]. Quando se diz que o mal é a privação de ser ou nada, entende-se que não se trata do nada anterior a criação. Pois, 
este consiste na pura inexistência de todas as coisas, ao passo que aquele é o "não mais existir" de uma coisa ou a sua corrupção [...]. O mal, contudo, é a privação, a corrupção do que é, isto é, da natureza, assim como se diz que o "imperfeito" é simplesmente o que não é "perfeito", a que somente se pode referir em relação a este (COUTINHO, 2010, p. 126-127).

A ideia de corrupção articula este processo de decadência do ser em direção ao não-ser. Existe uma íntima ligação ontológica entre os conceitos de bem e de ser. Desta maneira, todas as substâncias existentes configuram-se como bem. Com efeito, só é passível de corrupção pelo mal aquilo que é um bem: "Se a coisa for totalmente corrompida, recairá no nada e deixará de existir" (ERCULINO, 2014, p. 9). Costa, ao elucidar a questão na obra $O$ problema do mal na polêmica antimaniquéia de Santo Agostinho, afirma que

[...] só o ser existe, e o ser é necessariamente bom, pois a corrupção não pode acontecer senão no que existe ou no bem; segundo, porque se há alguma coisa de má nos seres criados, isso não aparece como uma característica intrínseca do ser ou não faz parte da essência do ser, mas, antes, como um contrário do ser, como uma ausência do que deveria ser, ou pelo que ele não é, ou como uma tendência ao nada (COSTA, 2002, p. 274).

Um dos grandes méritos legados por esta teoria da nulidade ontológica do mal desenvolvida pelo filósofo, consiste em exaltar a dignidade da obra da criação. Para melhor nos apercebermos disto, faz-se mister que tornemos a seus escritos, onde numerosas vezes exalta a constituição da natureza como um bem. O capítulo XIII do Livro III de O livre-arbítrio, nos oferece um dos textos agostinianos mais claros e profundos no que toca a afirmação da ideia acima referida. Agostinho parte daquilo que ele próprio chama de "Princípio fundamental", segundo o qual "todo ser é bom. O mal é uma privação”. Assim, ele ensina a Evódio: 
Toda natureza (natura) que pode tornar-se menos boa, todavia, é boa. De fato, ou bem a corrupção não lhe é nociva, e nesse caso ela é incorruptível; ou bem, a corrupção atinge-a e então ela é corruptível. Vem a perder a sua perfeição e torna-se menos boa. Caso a corrupção privar totalmente de todo bem, o que dela restará não poderá mais se corromper, não tendo mais bem algum cuja corrupção a possa atingir e, assim prejudicá-la. Por outro lado, aquilo que a corrupção não pode prejudicar também não se pode corromper, e assim esse ser será incorruptível. Pois eis algo totalmente absurdo: uma natureza tornar-se incorruptível por sua própria corrupção (SANTO AGOSTINHO, 1995, p. 191).

Esta leitura de Agostinho nos permite pensar a natureza e a criação, desde uma dupla perspectiva muito bem explicitada pelo doutor de Hipona. Toda obra criada ou é incorruptível ou então está sujeita à possibilidade de sofrer corrupção. De qualquer maneira, o criado constitui-se inequivocamente como bem, uma vez que se encontra de forma necessária atrelado ao divino, que é, pois, o bem por excelência. Ele assim o diz:

Por isso, se diz, com absoluta verdade, que toda natureza enquanto tal é boa. Mas se ela for incorruptível será melhor do que a corruptível. E se ela for corruptível - já que a corrupção não pode atingi-la senão tornando-a menos boa, ela é indubitavelmente boa. Ora, toda natureza ou é corruptível ou incorruptível. Portanto toda natureza é boa. Denomino "natureza" o que habitualmente se designa pela palavra "substância". Consequentemente, posso dizer que toda substância é Deus ou procede de Deus, e assim tudo o que é bom é Deus ou procede de Deus (SANTO AGOSTINHO, 1995, p. 192).

Nota-se aqui a subjacência de uma categoria fundamental em sua metafísica, que perpetuará nos mais diversos segmentos do pensamento filosófico cristão nos séculos seguintes: a ordem. O mal é refutado a partir da afirmação da existência de uma ordem natural que revela a perfeição da criação e, portanto, da exclusiva existência criada do bem. Percebemos que, assim como em todas as suas principais obras, a temática do mal é fortemente evidenciada e 
problematizada, da mesma forma, a sua nulidade é explicada a partir destas noções.

\section{Considerações finais}

Toda a metafísica agostiniana está alicerçada na teologia. Deus é o ponto de partida e de articulação de todo o seu pensamento. Com efeito, Deus “é aquele que é". É a plenitude do Ser, todas as outras criaturas, inclusive o homem, são porque participam do ser de Deus. Ele, contudo, não é o autor do mal. Afinal, como poderia Deus, princípio e razão de todo o bem, aquele que é o Bem em si, supremo e imutável gerar o mal?

Agostinho, com genialidade e perspicácia, responde aos maniqueus que pregavam a existência de dois princípios ontológicos contrapostos e em permanente estado de tensão: o bem e o mal. Para o doutor de Hipona o mal não existe como ser. O mal efetivamente "não é" pois não possui concretude ontológica. Só existe em relação ao Ser e ao Bem. Tal relação, contudo, é de falta, afastamento, privação. Ao mal atribui-se então um forte sentido ético e antropológico. Isto porque deriva dos atos morais humanos. O filósofo obtém, assim, notável êxito na empreitada de refutar a culpabilidade de Deus pela existência do mal. E é justamente na categoria de livre-arbítrio que encontra a resposta e a solução. O mal decorre exclusivamente da preferência humana, de seu aprisionamento aos chamados bens materiais, corruptíveis e à rejeição daquilo que é eterno. Deste modo, acaba por afastar-se de Deus gerando o não-ser.

Após concluir este trajeto argumentativo e reflexivo, nos deparamos com importantes respostas, mas, indubitavelmente com incontáveis novas interrogações. Tal situação é inevitável tratandose de uma reflexão filosófica. Do solo rígido de cada solução, brotam inúmeros problemas. Certamente revisitar Agostinho, é embarcar em uma viagem em direção a uma fonte que não se esgota. Por diversas vezes, ressaltou-se a importância de olhar para o mal 
através de um olhar filosófico crítico em razão da atualidade da questão. Pensar a filosofia a partir de seus problemas, é um convite a mergulhar com intensidade na tradição e no passado filosófico, buscando colher aí a maior quantidade possível de elementos que alicercem a discussão que vai, passo a passo, sendo construída em nossos dias. Agostinho é um autor paradigmático, um "divisor de águas na história da filosofia”, alguém que, em relação ao mal (bem como em relação a tantos outros problemas), inaugurou um novo status quo.

\section{Referências}

ABBAGNANO, Nicola. Dicionário de Filosofia. Trad. Alfredo Bossi, Ivone Castilho Benedetti. 5. ed. São Paulo: Martins Fontes, 2007.

BOEHNER, Philotheus; GILSON, Etienne. História da filosofia cristã: desde as origens até Nicolau de Cusa. Trad. Raimundo Vier. 8. ed. Petrópolis: Vozes, 2003 .

COELHO, Cleber Duarte. A nulidade ontológica do mal em Agostinho. Seara Filosófica, Pelotas, n. 6, Inverno, 2013.

COSTA, Marcos Roberto Nunes. O problema do mal na polêmica antimaniquéia de Santo Agostinho. Porto Alegre: Edipucrs; Recife: Unicap, 2002.

COUTINHO, Gracielle Nascimento. O livre-arbítrio e o problema do mal em Santo Agostinho. Argumentos: Revista de Filosofia, Fortaleza, ano 2, n. 3, p. 124131, 2010.

ERCULINO, Siloe Cristina do Nascimento. As origens do mal em Agostinho. Pensando: revista de filosofia, Teresina, v. 5, n. 10, p. 3-16, 2014.

GILSON, Etienne. Introdução ao estudo de Santo Agostinho. Trad. Cristiane Negreiros Abbud Ayoub. São Paulo: Discurso Editorial; Paulus, 2006.

HIRSCHBERGER, Johannes. História da filosofia na antiguidade. Trad. Alexandre Correia. São Paulo: Herder, 1957. 
192 | Revista Opinião Filosófica, Porto Alegre, V. 09; Nº. 01, 2018

MONTENEGRO, Santiago Cantera. San Agustín y la presencia del mal em la historia. Espíritu, v. 61, n. 144, p. 225-246, 2012.

PLATÃO. A república: livro VII. Trad. Elza Moreira Marcelina. São Paulo: Ática, 1989.

NUNES, Mariciane Mores. Livre-arbítrio e ação moral em Agostinho: um estudo a partir do De liberto arbítrio. Porto Alegre: Universidade Católica do Rio Grande do Sul, Faculdade de Filosofia e Ciências Humanas Pontifícia, 2009 .

REALE, Giovanni; ANTISERI, Dario. História da filosofia: Antiguidade e Idade Média. 5. ed. São Paulo: Paulus, 1990. v. 1.

RUSSEL, Bertrand. História da filosofia ocidental. Trad. Brenno Silveira. 3. ed. São Paulo: Companhia Editora Nacional, 1969.

SANTO AGOSTINHO. Confissões. 9. ed. Trad. J. Oliveira Santos; A. Ambrósio de Pina. Petrópolis: Vozes, 1988.

. O livre-arbítrio. Trad. Nair Assis Moreira. São Paulo: Paulus, 1995. Patrística.

SVENSSON, Manfred. Variaciones sobre el mal en san Agustín. Revista de Filosofia, Santiago, Chile, n. 61, p. 65-78, 1. 2009.

ULLMANN, Reinholdo Aloysio. O mal. Porto Alegre: Edipucrs, 2005. 